\title{
Effectiveness of Naira Devaluation on Economic Growth in Nigeria
}

\author{
Osundina Kemisola C. ${ }^{1}$, Osundina Jacob A. ${ }^{2}$ \\ ${ }^{1}$ Department of Economics, Banking and Finance, Babcock Business School, Babcock University, Ilishan-Remo, Ogun state Nigeria \\ ${ }^{2}$ Department of Accounting, Babcock Business School, Babcock University, Ilishan-Remo, Ogun State, Nigeria
}

\begin{abstract}
Currency devaluation as a policy instrument has been used in several countries (both developing and developed). The decision taken by monetary policy committee in November 2014 on naira devaluation has generated a lot of arguments both for and against and its workability on an import driven economy like Nigeria. Renowned economists in the country have not had any consensus hence the need to analyse the effectiveness of currency devaluation in Nigerian economy. Exchange rate, import, export and interest rates were used as proxies for currency devaluation, while real GDP was used to measure growth. The result of the analysis which is in line with the a priori expectation shows that devaluation reduces importation; encourages exportation and increases interest rate. Inflation and unemployment are the side effects of currency devaluation in the short run according to Marshall-Lerner's condition which produces a J-shaped curve of devaluation. Discretionary policies such as fiscal measures should be put in place to curb the associated increase in inflation.
\end{abstract}

Keywords: Currency Devaluation, Inflation, Unemployment, Exchange Rate, Export, Interest Rate.

\section{Introduction}

Currency devaluation is a deliberate downward adjustment of the value of a country's currency relative to another currency or standard currency (usually dollars). It is one of the tools of monetary policy to stabilize the economy most especially the less developed ones operating fixed exchange rate or semi-fixed exchange rate. Upadhyaya and Upadhyay (1999) as cited in Ould-Mey (2003) say it consists of large one-shot devaluation, series of devaluations or a policy of gradual exchange rate devaluation. One major policy option for a country facing a persistent balance of payments deficit is devaluation of its currency (Bahmani-Oskooee 1985).

In 1973, the United State of America devalued her currency by $10 \%$ after which Nigeria devalued Naira for the first time by the same amount. The effect of devaluation was salutary as Nigeria's foreign exchange reserves grew by $773.5 \%$ in 1974. In November 2014, the Central Bank of Nigeria (CBN) among other things moved the bench mark interest rate called Monetary Policy Rate from 12 to 13 per cent, and increased private sector's Cash Reserve Ratio from 15 to 20 per cent coupled with the devaluation of Naira by $8 \%$ (N13) from N155 to N168.

Devaluation increases international competitiveness of domestic industries which leads to diversion of consumption of foreign goods to domestic goods (Yilkal, 2014). It is used to encourage exportation, discourage importation and to correct unfavourable balance of payment by making home goods cheaper to foreign countries and foreign goods expensive in the home country. Examining the economy of Estonia, Parts (2013) observed that external devaluation was not going to work for the economy rather, internal devaluation was adopted coupled with other fiscal policy measures and that is why she had a quick recovery from the recent recession and its economy is in better shape than before the crisis. Estonian exports grew 22 percent in 2010 and 25 percent in 2011. This is a result of the rapid increase of high value-added exports by the manufacturing sector, which has also been the main job creator since the crisis. Indeed, export growth has been the main driver of the Estonian economic recovery (Parts, 2013). China achieved its "miraculous" growth as a result of blatant currency manipulation that effectively stole growth from many of its trading partners. Between 1978 and 1993, China's government pushed down the value of the renminbi by nearly two-thirds. In his book, "Devaluing to Prosperity", Bhalla says the value of the currency then nearly halved again between 1994 and 2011 (Berry, 2012).

Nigeria's GDP was recently rebased with the result placing the country as Africa's largest economy with an annual GDP of $\$ 510$ billion. Nigeria's population and the size of the market has remained an attraction for FDI inflow with the current population estimate projected at 183 million people in 2015 (growing at a projected growth rate of 2.82\%). The country is currently ranked the 7th most populous country in the world and has enjoyed a positive GDP growth rate in the last 10 years and a relatively stable exchange rate regime. Between the first quarter of 2013 and the last quarter of 2014 Nigeria posted an average GDP growth rate of 5.8\%, a single digit inflation of $8.2 \%$ in the last quarter of 2014 and a relatively stable exchange rate regime. The country is now in dilemma of the effect of further devaluation of naira as the former CBN governor, Sanusi Lamido and some other renowned Nigerian economists are clamoring for it while others like Tella, Teriba and Utomi see this as no solution to the economic problem facing the country. This study seeks to contribute to literature by empirically testing the effectiveness of Naira devaluation in Nigeria which is import driven and only exports crude oil and a few raw materials with low value added. A recent review of crude oil price shows a sharp decline of about 48.5 per cent between 2014 and 2015. Hence the need to know effective this last result tool will be in Nigeria. 


\section{International Journal of Science and Research (IJSR) \\ ISSN (Online): 2319-7064 \\ Index Copernicus Value (2013): 6.14 | Impact Factor (2014): 5.611}

\section{Literature Review}

\subsubsection{Concept of devaluation}

Farhi, Gopinath and Itskhoki (2012) define fiscal devaluation as a set of tax policies that, together with an adjustment in the money supply, will result in the same real economic allocations (consumption, output, and labor supply) as would be achieved by a nominal exchange rate devaluation. Argentina's Peso has been devalued by $20 \%$ with the belief of the New developmentalists in export led economic growth with a greater role for the state than the neoliberal views on the basis of a devalued currency, lower wages, and a relatively stable macroeconomy. They advocate for sound fiscal policy and recommend that government should operate surpluses in order to curb inflation that might result from it, they belief that, bringing down the country's real exchange rate was inevitable and necessary to promote greater competitiveness and growth (Vernengo, 2014). Whereas, the alternative views, is based on the old Structuralist school which emphasized the structural constraints on economic growth and development, most especially developing countries' need for income and wealth redistribution to promote domestic demand and the need to overcome their subordinate position in the world economy. To them, devaluation was not inevitable and is not particularly good. First, it will be inflationary, since it will lead to higher prices of imported goods, which includes intermediate and capital goods needed for production, and might lead to demands for higher nominal wages, once workers' purchasing power falls. Also, they said, devaluation might be contractionary, causing output to fall since lower real wages will lead to a contraction of demand. Further, devaluation tends to favor exporters, and benefit the agribusiness sector, by redistributing income towards groups with a lower propensity to spend, so also contributing to the contraction of demand. In short, the Structuralists argue that the devaluation will worsen inflation, in this sense; devaluation will not solve any of the pressing problems. Currency devaluation does not create wealth but it distributes wealth across the boundaries of nation, state or currency zone regions (Ould-Mey, 2003). Internal devaluation was used to combat financial crisis in Estonia because external devaluation was not an option to the economy and it helped to solve unemployment problem and European debt crisis (Parts, 2013).

\subsubsection{Concept of Economic Growth}

Economic growth is the increase in the market value of the goods and services produced by an economy over time. It is conventionally measured as the percent rate of increase in real gross domestic product, or real GDP. Between 1960 and 1970, GDP recorded 3.1 per cent growth annually as driven by agricultural sector, between 1970 and 1980 which is oil boom era, Nigeria recorded a remarkable increase in GDP of 6.3 per cent annually. In the early 1980s, the growth rate reduced but from 1986, as a result of structural adjustment and economic reform, there was an improvement because GDP increased at the rate of 4 per cent. The GDP in Nigeria averaged 1.32 percent between 2013 and 2015. The highest growth rate was achieved in the third quarter of 2015 which was 9.19 per cent. Services sector being the largest sector of the economy accounted for 50 per cent of the GDP while the fastest segment is information and communication.
Agricultural sector, which used to be the biggest sector with high potential for employment, accounts for 26 per cent and oil sector accounts for just 11 per cent. The effect of undervaluation on growth appears to be large and highly significant, also, stronger for developing countries (Rapetti, Skott, \& Razmi, 2012).

\subsubsection{Theoretical Framework}

The conventional answer to currency devaluations is analyzed within the Mundell-Fleming model and the result is a positive effect on the current account. Thus, devaluation is expansionary in terms of GDP since exports increase more than imports.

The Mundell-Fleming model, which is commonly known as the IS-LM-BoP model, is an economic model set forth by Robert Mundell and Marcus Fleming as an extension of the IS-LM Model. The traditional IS-LM Model deals with economy under autarky, the Mundell-Fleming model describes a small open economy. Mundell's paper suggests that the model can be applied to Zurich, Brussels and so on (Mundell, 1963 \& Fleming, 1962).

The Mundell-Fleming model shows the short-run relationship between an economy's nominal exchange rate, interest rate, and output in contrast to the closed-economy IS-LM model, which focuses only on the relationship between the interest rate and output. The argument that an economy cannot simultaneously maintain a fixed exchange rate, free capital movement and an independent monetary policy has been solved by Mundell-Fleming model. This principle is frequently called the "impossible trinity," "unholy trinity," "irreconcilable trinity," "inconsistent trinity" or the "Mundell-Fleming trilemma." This model uses the following variables: $Y$ is GDP, $C$ is consumption, $I$ is physical investment, $G$ is government spending (an exogenous variable), $M$ is the nominal money supply, $\mathrm{P}$ is the price level, I is the nominal interest rate, L is liquidity preference (real money demand), $\mathrm{T}$ is taxes, $\mathrm{NX}$ is net exports. The Mundell-Fleming model is based on the following equations:

The IS curve: $Y=C+I+G+N X$,

The LM curve, $M / P=L(i, Y)$.

A higher interest rate or a lower income (GDP) level leads to lower money demand.

The BoP (Balance of Payments) Curve: $B O P=C A+K A$

Where $\mathrm{BoP}$ is the balance of payments surplus, $C A$ is the current account surplus, and $K A$ is the capital account

\section{surplus.}

Mundell-Fleming model might be naturally extended by considering many other important features, which determine the degree of the reaction of the current account, such as: (i) the price elasticity of world's (country's) demand for tradable goods, i.e., the variation of the exports (imports) in response to a real exchange rate variation; and (ii) the presence of supply shocks effects due to the presence of intermediate inputs and raw materials, e.g., oil, which might generate inflationary pressures (Saibene \& Sicouri, 2012). 


\section{International Journal of Science and Research (IJSR) \\ ISSN (Online): 2319-7064 \\ Index Copernicus Value (2013): 6.14 | Impact Factor (2014): 5.611}

Devaluation reduces balance of payment deficit but may not be true in all cases. Therefore, effectiveness of devaluation depends on Marshall-Lerner condition which states that when the sum of price elasticity of the demand for imports of any two countries trading their goods between them is greater than unity, then devaluation increases exports and decreases imports (Dwivedi, 2001). He states further that devaluation reduces BOP deficit when the sum of price elasticity of A's demand for imports and price elasticity of B's demand for A's exportable, in absolute terms is greater than unity. Also it increases BOP deficits when the sum of price elasticity of demand for imports of a country and the price elasticity of demand for its exportable in absolute terms is less than unity. Further, when the sum of price elasticity of demand for importable of a country and the price elasticity of demand for its exportable, in absolute terms equals one, then devaluation leaves the trade balance unchanged and hence BOP remains unaffected. The empirical evidence shows that in the short run devaluation causes deterioration in the BOP, this is due to the tendency for import prices to rise faster in the domestic market immediately after devaluation than the export prices without much changes in the quantities imported and exported. This is what produces a J- shaped curve which the economists call J-curve effect of devaluation. Davidson (2006) asserts that Marshall -Lerner's condition does not apply to a country like United state because despite a significant decline in the value of the dollar, the trade imbalance has almost doubled which may lead to depression if not properly handled.

Junz and Rhomberg (1973) as cited in Bahmani-Oskooee (1985) have argued that the expansion of exports and the retardation of imports occur only after substantial lags. They have identified at least five lags in the process between changes in exchange rates and their ultimate effects on real trade: lags in recognition of the changed situation, in the decision to change real variables, in delivery time, in the replacement of inventories and materials, and in production. Their empirical evidence supports lags of up to five years in the effects of exchange rate changes on market shares of countries in world trade. Trading activities of a country are stimulated with overall purpose of enhancing economic growth and development and ultimately to alleviate poverty (Aiya, 2014). Kennedy (2015) while debating on whether Europe can save itself by devaluing Euros says that devalued euro brings economic growth and associated inflation in a very export driven economy.

\subsubsection{Empirical Framework}

Bahmani-Oskooee (1985) investigated the J-curve phenomenon for Greece, India, Korea and Thailand and found evidence in favour of the J-curve effect for all the countries except for Thailand. In particular, it took two quarters, four quarters and three for the trade balance of Greece, India and Korea to deteriorate after devaluation. For Thailand, the trade balance at the onset improves for five quarters subsequent to a devaluation policy and thereafter deteriorated. Aiya (2014) assessed people's perception on the impact of devaluation of Nigerian currency on the performance of poverty alleviation programmes in Edo state Nigeria, using Primary data and chi square statistical analysis, he found that currency devaluation limits the performance of poverty alleviation programmes in Edo state.
He recommends that there should be proper funding of Poverty Alleviation Programmes because the devaluation of currency as often recommended by the Bretton Wood institutions such as IMF and the World Bank has resulted in hyper inflationary trend in the economy. Devaluation is expansionary in terms of GDP since exports increase more than imports according to Mundell-Fleming model but based on the result of Saibene et.al, (2012), they concludes that devaluation is contractionary for countries with a large amount of debt dominated in a foreign currency whereas, they are not for the countries whose debt is denominated in their own currency all things being equal. They also assert that after sharp currency devaluations, the debt burden increases in real terms, leading to the following chain of events: firms' profits decrease, bank lending is constrained, and thus the amount of investment is sharply reduced, reducing also next period output. Because the question of determining optimal policy is very important for many economies in the world, Hevia and Nicolini (2013) studied the optimal response of monetary and exchange rate policy to a change in the price of a commodity of that of a small open economy actively trades in international markets. They found that there is a reasonable parametrization of the model that is able to reproduce the observed volatility of the nominal exchange rate and its correlation with commodity prices. Farhi et al (2012) consider the cases of producer and local currency price setting with some price stickiness, as the real effects of nominal devaluations depend on whether prices are set in the producer's currency or in local currency. Their model features two countries, home and foreign, the foreign with a passive policy of a fixed money supply. The home country can alter its money supply and also potentially use six different fiscal instruments to achieve the policy goal that mimics a nominal devaluation but maintains a fixed nominal exchange rate: import and export tariffs, a valueadded tax (with border adjustment), a payroll tax paid by producers, and consumption and income taxes paid by consumers. The authors consider various degrees of capital account openness: balanced trade (financial autarky), complete risk-sharing with Arrow-Debreu securities (securities that are paid in only one time period), and an arbitrary net foreign asset position. They found out that the two fiscal devaluation policies that mimic nominal exchange rate devaluations are: (1) a uniform increase in import tariffs and export subsidies and (2) a uniform increase in valueadded taxes and a reduction in payroll taxes.

Siddig (2012) examined exchange rate devaluation in Sudan using computable general equilibrium .The paper reports the impact of devaluation on several economic indicators considering domestic commodity markets, the factors market and institutions. Responses of specific economic variables such as prices, household demand, welfare, and the balance of payment are used to describe the resulting equilibriums of the economy as a result of devaluations in the three scenarios. The results reveal that devaluation of the Sudanese pound will considerably increase most domestic commodity prices. This is desirable for producers who target the world market because their returns in the local devalued currency will tend to be higher. Accordingly, export oriented sectors, which have a larger share of exports in their total output, show the greatest increases in output and exports compared to other sectors. He concludes that, devaluation of 


\section{International Journal of Science and Research (IJSR) \\ ISSN (Online): 2319-7064 \\ Index Copernicus Value (2013): 6.14 | Impact Factor (2014): 5.611}

Sudan's currency would increase domestic prices of tradable goods and encourage producers to export. However, domestic consumers are negatively affected because the increase in prices is unaccompanied by similar increases in household income. This could also lead domestic production to deteriorate at a certain point in time since the cost of intermediate inputs will also increase especially imported intermediate inputs. Therefore, devaluation would encourage producers of some sectors to increase output and exports, while it would hinder consumers to enjoy the previously cheaper imported and domestic commodities since domestic prices increase. Newton (2013) while reviewing sterling devaluation between 1968 and 1970 explained the travails of the British labour government and that it took a year to convince people on the need for devaluation which paid off at last. Ould-Mey (2003) examined currency devaluation and resource transfer from southern (ex-colonized) to the Northern (ex-colonizer) countries and found that the resource transfer from the south to the North was contributed to by currency devaluation by devaluation of the export from the South and over valuation of modern exports. In a study conducted by Soukiazis, Cerqueira, \& Antunes, (2013) on the effect of external and internal imbalances as well as role of relative prices on growth rate in Portugal found that currency devaluation is a stimulus to growth which is increasing the country's competitiveness in the foreign market.

Kogid, Asid, Lily, Mulok, \& Loganathan (2012). Carried out a research on the effect of exchange rates on Economic Growth, using nominal and real exchange rate, they found out that both exchange rates, nominal and real, are considered to have similar effects on economic growth. The results of ARDL bounds test suggest that long-run cointegration exists between both nominal and real exchange rates and economic growth with a significant positive coefficient recorded for real exchange rate. In addition, the results of ECM-based ARDL also reveal that both exchange rates have a similar causal effect towards economic growth.

\section{Model Specification, Analysis and Discussion of Findings}

Ordinary least square method was used to analyse the set of data which are time series in nature. The unit root analysis was carried out and the data were stationary at first difference due to this fact, the data were differenced.

The model is specified as follows:

$D E X R=\beta_{0}+\beta_{1} D I M P+\beta_{2} D E X P T+\beta_{3} D I N T R+\mu$

And the resulting model is as follows;

$D E X R=-1.8563-0.000012 D I M P+0.00185 D E X P T$

$$
+2.97 D I N T R
$$

From the model, exchange rate which indicates currency devaluation has an inverse and significant relationship with import rate. It has a direct and significant relationship with export rate as well as a direct and significant relationship with interest rate. The inverse relationship between currency devaluation and import is expected because currency devaluation reduces importation as the value of local currency decreases and importation becomes unbearably expensive. This makes consumption of locally made goods mandatory. The direct relationship between exchange rate and export rate is equally expected, which means that as exchange rate increases that is, local currency is devalued, export rate increases. This occurs because the local goods become cheaper and affordable in international market, so export increases. This is in line with the statement of Yilkal (2014) that devaluation increases the competitiveness of local goods in international market. Also interest rate and exchange rate are significantly related, this is also expected because as export rate increases, manufacturers are motivated to produce more and are willing to invest more which may automatically increase the exchange rate. The coefficient of determination $\mathrm{R}^{2}$ shows that $90.4 \%$ of the variations in exchange rate are explained by variations in import rate, export rate and interest rate, while the remaining $9.6 \%$ are not explained within the model. The model is statistically fit to explain currency devaluation in that Fstatistic is 92.0286 and the associated probability (0.0000000) is less than 0.05 (level of significance).

\section{Conclusion and Recommendation}

Devaluation of currency is not a bad idea to solve the economy's balance of payment problem in Nigeria because overtime, it has been used by other countries. Sound fiscal policy should be ensured so that the resulting inflation and workers unrest in a bid to demand for higher income could be curbed. This study identified also that diversification of export is inevitable for Nigeria to achieve economic growth in the face of devalued currency. Also, in order to reduce import dependency of Nigeria, the government should step up policy to spur domestic industry as the new rebased GDP shows that in the first and second quarters of 2014, industry and construction contributed marginally (Monetary policy review, August 2014). Government procurement from domestic producers, domestic-content requirements on international producers seeking access to the country's markets, subsidized credit for industrial development, and increased support for research and development are highly recommended. According to the speculation of J-curve of devaluation, every economy must expect deterioration at the short run of the policy but if the policy is carefully guided and mixed with sound fiscal policy, the economy will improve in the long run. However the period it takes to weather the situation differs from one country to the other. It has been established that currency devaluation can lead to economic growth for an export driven economy but the problem with Nigeria is that the nation is import-driven. The content of export has little or no value added. The export in Nigeria is predominantly crude oil whose price has dropped drastically and the currency devaluation policy can only be effective for an industrialized economy. It is recommended that naira should not be devalued further until we improve on the quality of goods being exported through industrialization so that global competiveness will be achieved and it can have a positive effect on the balance of payment. Contractionary policies should also be put in place to curb the associated increase in inflation.

There is no doubt that initially a common man in Nigeria will not enjoy it because the policy is channeled towards encouraging exportation and discouraging importation. Currency devaluation has lead to inflation in many cases and 


\section{International Journal of Science and Research (IJSR) \\ ISSN (Online): 2319-7064 \\ Index Copernicus Value (2013): 6.14 | Impact Factor (2014): 5.611}

Nigeria's own may not be an exemption. Hopefully, the other policy instruments will combat inflation.

\section{References}

[1] Aiya, F. (2014). People's Perception of the Impact of Currency Devaluation on the Performance of Poverty Alleviation Programmes in Nigeria, Developing Country Studies IISTE, 4, (10), 7-16.

[2] Bahmani-Oskooee, M. (1985). Devaluation and the Jcurve: Evidence From LDCs, The Review of Economics and Statistics, 67, (3) 500-504.

[3] Berry, J. M. (2012). Every Man a Currency Manipulator. International Economy, 26(4), 33-71.

[4] Davidson, P. (2006). The declining dollar, global economic growth, and macro stability. Journal of Post Keynesian Economics, 28(3), 473-493.

[5] Dwivedi, D.N. (2001). Macroeconomics Theory and Policy, Tata McGraw-Hill Publishing Company Limited, New Delhi.

[6] Farhi, E., Gopinath, G., \& Itskhoki, O. (2012). Fiscal Devaluations. Research Review, (18), 40- 43.

[7] Fleming, J. Marcus (1962). "Domestic financial policies under fixed and floating exchange rates". IMF Staff Papers 9: 369-379. doi:10.2307/3866091.

[8] Hevia, C., \& Nicolini, J. P. (2013). Optimal Devaluations. IMF Economic Review, 61(1), 22-51. doi:10.1057/imfer.2013.2

[9] Kennedy, S. (2015). Can Europe Save Itself By Weakening the Euro?. Bloomberg Businessweek, (4411), 20-21.

[10] Kogid, M., Asid, R., Lily, J., Mulok, D., \& Loganathan, N. (2012). The Effect of Exchange Rates on Economic Growth: Empirical Testing on Nominal Versus Real. IUP Journal Of Financial Economics, 10(1), 7-17.

[11] Mundell, Robert A. (1963). "Capital mobility and stabilization policy under fixed and flexible exchange rates". Canadian Journal of Economic and Political Science 29 (4): 475-485. doi:10.2307/139336

[12] Monetary Policy Review, Central Bank of Nigeria, August 2014, page 2.

[13] Newton, S. (2013). Sterling, Bretton Woods, and Social Democracy, 1968-1970. Diplomacy \& Statecraft, 24(3), 427-455. doi:10.1080/09592296.2013.817931

[14] Ould-Mey, M. (2003). Currency Devaluation and Resource Transfer from the South to the North. Annals Of The Association Of American Geographers, 93(2), 463-484. doi:10.1111/1467-8306.9302012

[15] Parts, J. (2013). Estonia and The European Debt Crisis. CATO Journal, 33(2), 269-274.

[16] Rapetti, M., Skott, P., \& Razmi, A. (2012). The real exchange rate and economic growth: are developing countries different?. International Review Of Applied Economics, 26(6), 735-753. doi:10.1080/02692171.2012.686483

[17] Saibene, G., \& Sicouri, S. (2012). Effects of Currency Devaluations on the Economic Growth in Developing Countries: The Role of Foreign Currency-Denominated Debt. Atlantic Economic Journal, 40(2), 191-209. doi:10.1007/s11293-011-9300-4

[18] Siddig, K. H. (2012). The Controversy of Exchange Rate Devaluation in Sudan: An Economy- wide General
Equilibrium Assessment. African Development Review, 24(3), 245-254. doi:10.1111/j.1467-8268.2012.00320.x

[19] Soukiazis, E., Cerqueira, P. A., \& Antunes, M. (2013). Growth rates constrained by internal and external imbalances and the role of relative prices: empirical evidence from Portugal. Journal of Post Keynesian Economics, 36(2), 275-298. doi:10.2753/PKE01603477360205

[20] Vernengo, M. (2014). Don't Cry for Argentina--Not Yet!. Dollars \& Sense, (311), 23. 